\title{
ARTI TIANG RUMAH TRADISIONAL SUKU BATIN DI KAMPUNG BARUH, JAMBI
}

\section{Meaning of Pole in Traditional Batin Tribe House at Kampung Baruh, Jambi}

\author{
Budi Wiyana \\ Balai Arkeologi Sumatera Selatan \\ Jalan Kancil Putih - Demang Lebar Daun, Palembang 30137 \\ E-mail: budi_wiyana@ymail.com \\ Naskah diterima redaksi: 13 Agustus 2015 - Revisi terakhir: 30 Oktober 2015 \\ Naskah disetujui terbit: 10 Juni 2016
}

\begin{abstract}
Traditional Batin Tribe house is a rectangular mapped stage house which aged about three hundred years old in Kampung Baruh, Jambi. The house has components and the division of space, each of which has a specific meaning. This paper aims to determine the meaning in the distinction of workmanship in building the poles in traditional Batineese houses. Methods of data collection of ancient settlements with the pole conducted by survey. Pole as one of the important components of traditional houses standing on the inner layer of wooden pedestals or cocked stone. The poles consist of $(6,8,12,16,18)$ sided shapes. The magnitude in the pole's side shows diameter and strength, also shows the owner has a higher social status than the owner of the house with less rectangular pole.
\end{abstract}

Keywords: meaning, poles, traditional houses, Batin Tribe, Kampung Baruh

\begin{abstract}
Abstrak
Rumah tradisional Suku Batin merupakan rumah panggung berdenah persegi empat yang telah berumur sekitar tiga ratus tahun di Kampung Baruh, Jambi. Rumah tersebut mempunyai komponen dan pembagian ruang yang masing-masing mempunyai arti tertentu. Tulisan ini bertujuan mengetahui arti perbedaan pengerjaan bentuk tiang rumah tradisional Suku Batin. Metode pengumpulan data permukiman kuna dengan bagian tiang sebagai kajiannya dilakukan dengan survei. Tiang sebagai salah satu komponen penting rumah tradisional Batin berdiri di atas tapakan umpak kayu atau batu. Tiang tersebut berbentuk segi $(6,8,12,16,18)$. Tiang rumah berbentuk segi lebih banyak menunjukkan besaran diameter dan kekuatannya, juga menunjukkan pemiliknya mempunyai status sosial lebih tinggi dibanding dengan pemilik tiang rumah berbentuk persegi lebih sedikit.
\end{abstract}

Kata kunci: arti, tiang, rumah tradisional, Suku Batin, Kampung Baruh

\section{PENDAHULUAN}

Kampung Baruh adalah salah satu bagian dari Desa Baruh, Kecamatan
Rantaupanjang, Kabupaten Merangin, Provinsi Jambi. Di daerah ini bertempat tinggal Suku Batin. Suku Batin sebagian besar bertempat tinggal di daerah 
sepanjang Sungai Tembesi beserta anakanak sungainya sampai ke bagian hulu. Secara administrasi daerah tersebut termasuk Kabupaten Bungo, Merangin, dan Sarolangun. Suku Batin adalah suku yang berasal dari daerah sebelah barat pegunungan Bukit Barisan (Sumatera Barat). Orang Batin membentuk kelompok genealogis dalam satuan hukum adat yang bersama-sama mewujudkan suatu masyarakat berhulu ibu (matrineal).

Suku Batin sampai saat ini masih mempertahankan adat-istiadat, terutama peninggalan-peninggalan adat berupa bangunan-bangunan tua. Banyak rumahrumah tradisional Suku Batin yang telah berusia sekitar 300 tahun. Bangunan tua tersebut menjadi obyek wisata yang menarik (Siregar, 2008: 541). Rumah tradisional Suku Batin oleh penduduk setempat terkadang juga disebut dengan rumah adat. Pada tulisan ini, rumah tua tersebut lebih tepat disebut dengan rumah tradisional. Rumah tradisional dapat diartikan sebagai sebuah rumah yang dibangun dan digunakan dengan cara yang sama sejak beberapa generasi (Sumintardja, 1981: 11).

Rumah tradisional atau rumah adat Suku Batin termasuk dalam kajian arsitektur vernakular. Vernakular berasal dari bahasa Latin vernaculus yang berarti asli, sedangkan arsitektur vernakular adalah arsitektur asli yang dibangun oleh masyarakat setempat. Banyak arsitektur vernakular yang terdapat di Indonesia, seperti di Aceh; Mentawai (Sakuddei); Palembang (Limas); Jawa; Bali; Sumba (Laboya); Flores (Tana 'Ai); Sawu; Timor (Atoni); Toraja (Tongkonang); Maluku Tenggara (Dawera dan Dawelor); dan Halmahera (Tabelo) (Nas, 1998: 336-343)

Rumah-rumah tradisional Suku Batin terdapat pada Marga Batin V Tabir di daerah Rantaupanjang dan Kampung Baruh, Kecamatan Rantaupanjang,

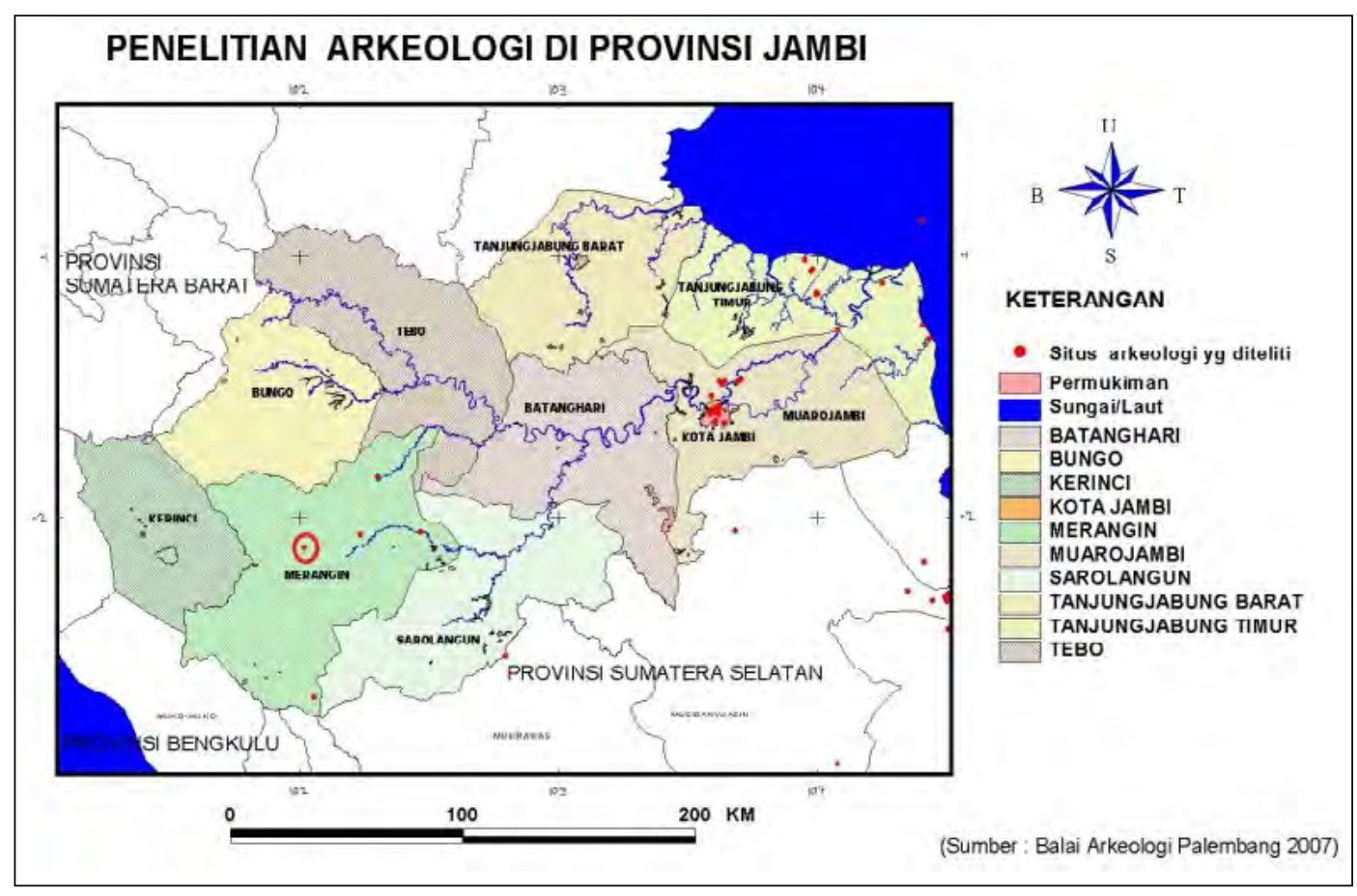

Gambar 1. Peta keletakan Kampung Baruh. (Sumber: Dokumen Balai Arkeologi Palembang, 2007) 
Kabupaten Merangin. Obyek kajian rumah tradisional di Kampung Baruh sebanyak 125 buah baik yang masih asli maupun yang sudah diperbaiki.

Bangunan rumah tempat tinggal orang atau Suku Batin disebut kajang lako, karena bentuk bubungan rumah tersebut mirip dengan perahu. Kedua ujung bubungan bagian atas dilengkungkan ke atas dan ke bawah berlipat dua sehingga membentuk segitiga. Rumah tradisional Batin merupakan rumah panggung dengan denah berbentuk empat persegi panjang. Bentuk rumah persegi panjang mempermudah dalam penyusunan ruangan yang disesuaikan dengan fungsinya (Darmansyah, 2002: 14).

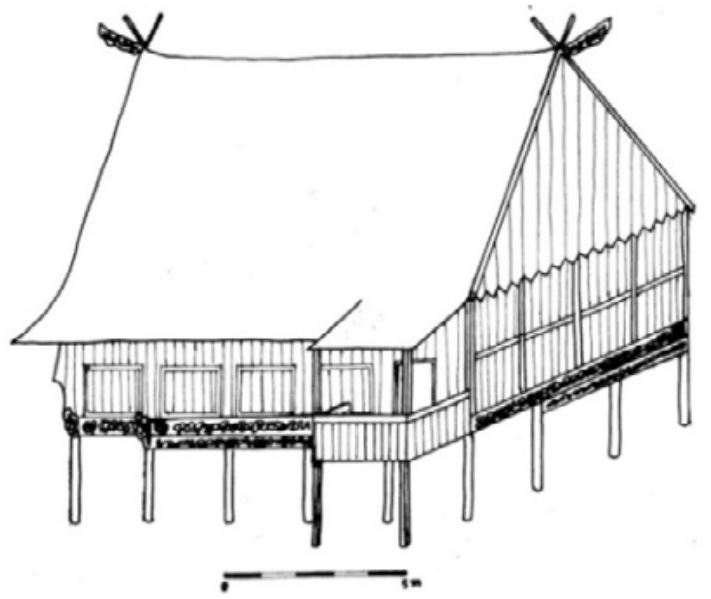

Gambar 2. Bentuk rumah tradisional Suku Batin. (Sumber: Wiyana, 2007)

Rumah tradisional di Kampung Baruh mempunyai denah dan ukuran yang hampir sama. Bahan rumah terbuat dari kayu ulin dengan atap aslinya dari ijuk. Sekarang atap rumah sudah banyak diganti dengan seng. Teknik penyambungan pada bagianbagian rumah tersebut tidak menggunakan paku maupun engsel besi melainkan memakai teknik tumpu dan teknik sambung kait atau pasak (Wiyana, 2000: 9). Teknik pasak rumah Batin termasuk ciri rumah tradisional yang berkembang di Asia Tenggara pada umumnya (Waterson, 1997: 115).

Bagian-bagian dari rumah kajang lako mempunyai arti dan simbol tertentu. Pada tulisan ini bagian rumah yang akan dikaji adalah bagian tiang. Permasalahan yang dibahas pada tulisan ini adalah apa arti (simbolis dan praktis) tiang rumah tradisional Suku Batin di Kampung Baruh, Jambi? Tujuan penulisan ini adalah mengetahui arti simbolis dan praktis bentuk tiang rumah tradisional Suku Batin. Kata simbol berasal dari kata Yunani symbolos yang berarti tanda atau ciri yang memberitahukan sesuatu hal kepada seseorang (Herusatoto, 2008: 17). Dengan diketahuinya arti simbolis dan praktis, diharapkan dapat diketahui kedudukan pemilik rumah dalam masyarakat tersebut.

Setiap masyarakat senantiasa mempunyai penghargaan tertentu terhadap hal-hal tertentu dalam masyarakat yang bersangkutan. Penghargaan yang lebih tinggi terhadap hal-hal tertentu akan menempatkan hal tersebut pada kedudukan yang lebih tinggi dari hal-hal lainnya. Kalau suatu masyarakat lebih menghargai kekayaan materiil daripada kehormatan (misalnya), mereka yang lebih banyak mempunyai kekayaan materiil akan menempati kedudukan yang lebih tinggi apabila dibandingkan dengan pihakpihak lain. Gejala tersebut menimbulkan lapisan masyarakat yang menggambarkan pembedaan posisi seseorang atau suatu kelompok dalam kedudukan yang berbedabeda secara vertikal. Sistem lapisan dalam masyarakat tersebut dalam sosiologi dikenal dengan stratifikasi sosial (social stratification) atau pelapisan sosial. 
Pada masyarakat-masyarakat yang kecil serta bersahaja, biasanya pembedaan kedudukan dan peranan bersifat minim karena warganya sedikit dan orang-orang yang dianggap tinggi kedudukannya juga tidak banyak, baik macam maupun jumlahnya. Di dalam masyarakat yang sudah kompleks, pembedaan kedudukan dan peranan juga bersifat kompleks karena banyaknya orang dan ukuran yang dapat diterapkan terhadapnya (Soekanto, 2012: 198).

Dasar dan inti penyebab terjadinya stratifikasi sosial adalah tidak adanya keseimbangan antara hak dan kewajiban di antara warga masyarakat. Akibatnya sesama anggota masyarakat menilai dan memilah-milah dan diakui ada perbedaan. Secara umum stratifikasi sosial dapat dibedakan berdasarkan kriteria ekonomi, sosial, dan politik (Syarbaini dkk., 2012: 108-111). Kerangka pikir ini dimaksudkan untuk memberi gambaran tentang stratifikasi sosial terhadap tulisan ini.

Adapun metode pengumpulan data dilakukan dengan survei terhadap permukiman kuna masa pengaruh Islam di Kabupaten Merangin yang dilaksanakan tahun 2007. Permukiman kuna yang mempunyai rumah tradisional/kuna dideskripsi secara lengkap, termasuk komponen-komponen rumahnya. Komponen rumah yang menarik untuk menjadi kajian dalam tulisan ini terutama adalah tiang rumah dan didukung ragam hiasnya. Semua tiang rumah tradisional dikelompokkan berdasarkan bentuk seginya. Berdasarkan analisis terhadap semua tiang, ternyata terdapat lima bentuk tiang (segi 6, 8, 12, 16, dan 18). Tiang rumah kebanyakan ditopang oleh umpak kayu, sedangkan lumbung padi ditopang umpak batu.

\section{HASIL DAN PEMBAHASAN}

Menurut adat Batin, pemilihan lokasi tanah yang akan dibangun harus memperhatikan beberapa pantangan. Pertama, bangunan tidak boleh menghadap ke lereng bukit, karena menurut kepercayaan penghuni rumah yang menghadap ke lereng bukit akan selalu ditimpa musibah kematian. Kedua, membangun rumah tidak boleh di hulu sungai, karena menurut kepercayaan masyarakat setempat orang yang membangun di sana akan ditimpa oleh berbagai macam penyakit (Madjid, 1986: 48-49).

Orang Batin sangat memperhatikan tata letak sehingga dalam perkampungan tidak ada rumah yang dibangun terpencar dan memisahkan diri. Rumah-rumah dibangun dalam beberapa deretan yang memanjang secara terpisah dan tertata dengan rapih. Jarak antara rumah satu dengan lainnya kira-kira dua meter. Rumah dibangun secara berhadap-hadapan dengan ditengahi oleh jalan. Lumbung sebagai tempat menyimpan padi dibuat di belakang rumah tempat tinggal atau ada sebagian juga yang dibangun di sawah.

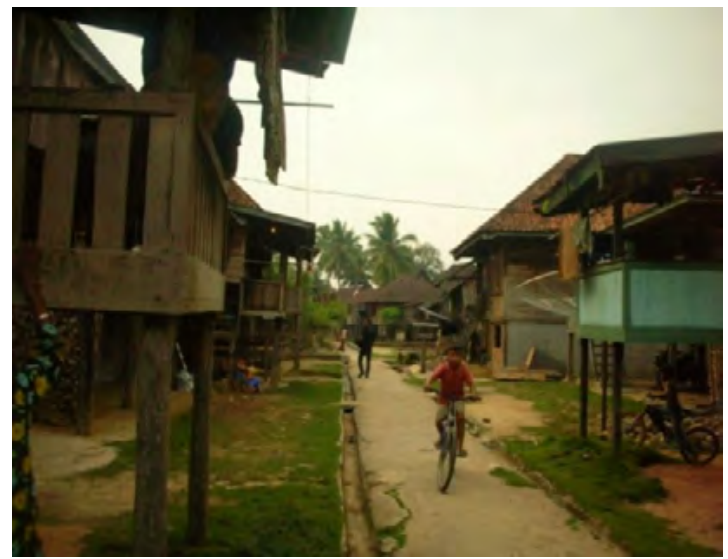

Gambar 3. Jalan yang terdapat di antara dua rumah yang saling berhadapan. (Sumber: Dokumen Balai Arkeologi Palembang, 2007) 
Rumah tradisional Suku Batin berupa rumah panggung dan berdenah persegi panjang. Bagian-bagian rumah kajang lako terdiri dari tangga, pelamban, ruang gaho, ruang masinding (ruang tempat duduk laki-laki), ruang tengah (ruang tempat duduk perempuan), ruang balik melintang, dan ruang balik menalam (kamar tidur anak gadis, kamar tidur orang tua, dan ruang makan).

Pelamban adalah bagian teras bangunan yang ada di bagian depan sebelah kiri bangunan induk. Ada dua pelamban (depan dan belakang). Fungsi pelamban depan sebagai tempat menjemur pakaian, sedangkan pelamban belakang sebagai tempat mencuci. Ruang gaho/gakho adalah ruangan memanjang dari pelamban depan sampai pelamban belakang. Ruang masinding adalah ruang depan yang berkaitan dengan masinding. Ruang ini dalam masyarakat adat dipergunakan untuk tempat duduk orang biasa/tamu. Pada waktu menerima tamu, wanita tidak diperkenankan duduk di ruangan ini karena ruangan ini khusus untuk tamu laki-laki. Ruang tengah berada tepat di tengah-tengah bangunan dan berfungsi sebagai tempat duduk perempuan. Ruang masinding dan ruang tengah tidak berdinding dan hanya dibatasi kayu panjang yang disebut bendul jati. Ruang balik melintang dibuat lebih tinggi dari lantai lainnya karena merupakan ruang

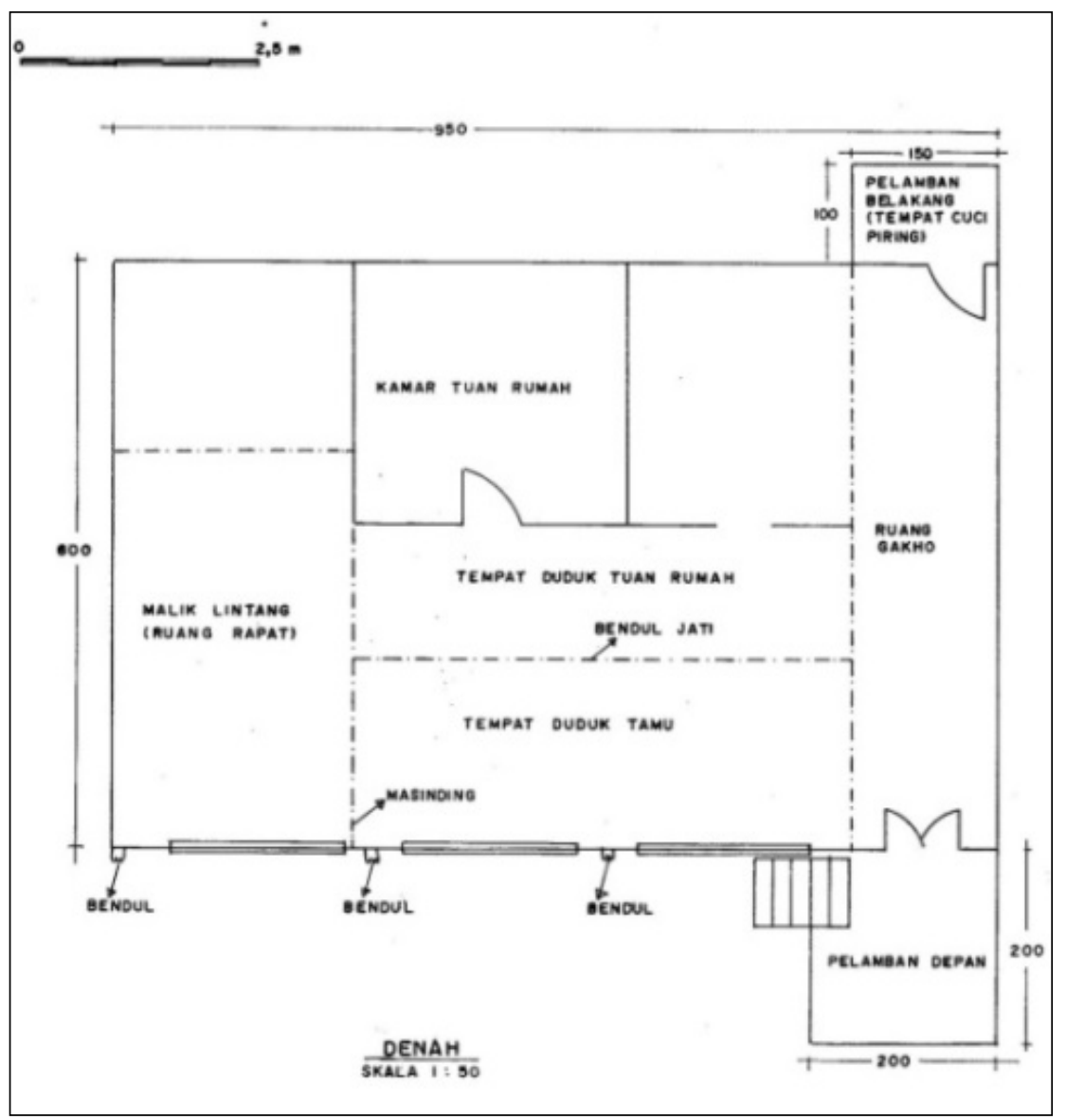

Gambar 4. Denah rumah Suku Batin. (Sumber: Wiyana, 2007) 
utama. Pada waktu upacara adat, ruang ini hanya khusus untuk pemuka adat, alim ulama, ninik mamak, dan cerdik pandai. Pada hari biasa atau saat pesta pernikahan, ruang ini dipergunakan sebagai ruang tamu dan tempat tidur anak gadis atau tempat tidur pengantin baru. Ruang balik menalam disebut juga dengan kamar dalam. Ruang ini terdiri dari tiga kamar, yaitu kamar makan (kiri, dekat gaho), kamar tidur orang tua (tengah), dan kamar tidur gadis.

Di samping ruang-ruang utama, rumah tradisional Batin juga terdapat ruang lainnya, seperti ruang penteh dan ruang bauman. Ruang penteh adalah ruangan atas atau loteng, sedangkan ruang bauman terdapat di bagian bawah bangunan. Pada ruang bawah atau ruang bauman terdapat 24 tiang yang disusun berjajar sebanyak enam deret. Tiang utama berbentuk persegi $(6,8,12,16$, dan 18). Pola tiang rumah berjumlah 24 adalah pola umum dan berlaku untuk seluruh rumah, baik warga biasa maupun kalangan tertentu (atas). Rumah tradisional Batin secara umum mempunyai ukuran yang hampir sama. Panjang atau tinggi tiang bisa mencapai setinggi rumah, terutama dua deret tiang yang berada di tengah. Dua deret tiang bagian pinggir (depan dan belakang) lebih pendek daripada bagian tengah. Tiang berdiri menembus lantai rumah.

Tiang berdiri di atas tapakan umpak dari kayu atau batu. Kebanyakan umpak tiang rumah berupa kayu, sedangkan tapakan tiang lumbung padi berupa batu. Perbedaan pemakaian umpak kayu dan batu disebabkan faktor beban yang didukungnya dan fleksibilitas. Rumah tentunya mempunyai beban lebih berat dibanding lumbung padi. Untuk tapakan dengan dukungan yang lebih berat lebih baik digunakan kayu dibanding batu. Kayu dipilih karena lebih fleksibel atau lentur dibanding batu. Tapakan secara kosmologi berfungsi untuk menolak energi bumi yaitu energi tanah yang diartikan sebagai gunung yang dianalogikan gempa dan kelembaban (Riany dkk., 2014: 12). Alasan ini kemungkinan juga untuk mengantisipasi guncangan apabila terjadi gempa bumi yang sering terjadi di dataran tinggi Jambi (Kerinci dan Merangin).

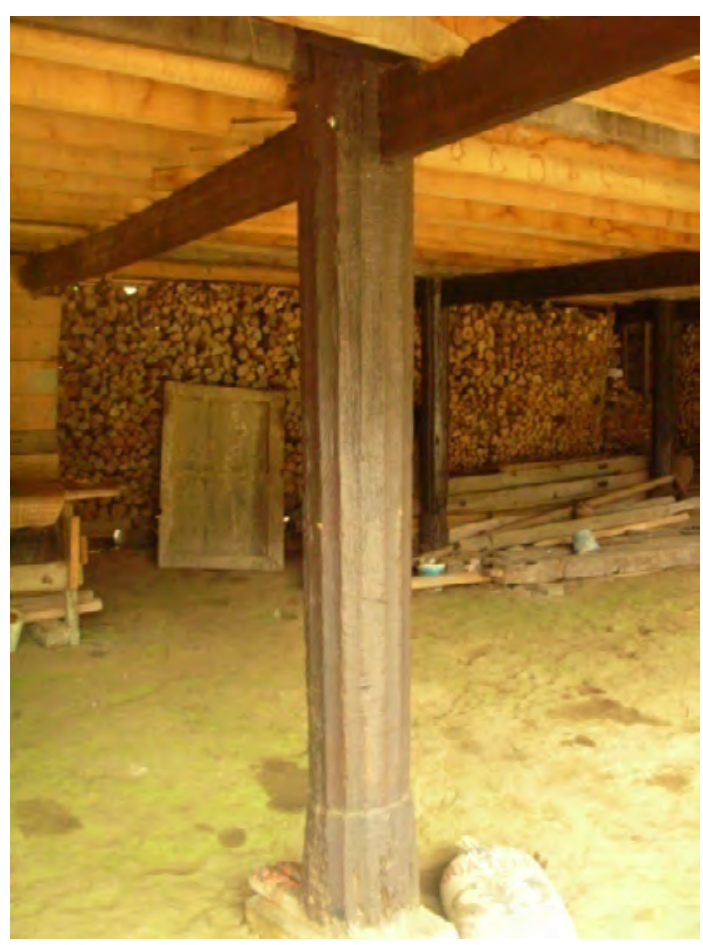

Gambar 5. Tiang yang menembus lantai rumah. (Sumber: Dokumen Balai Arkeologi Palembang, 2007)

Ada empat faktor yang sangat menentukan dalam membentuk model hunian. Keempat faktor tersebut adalah kondisi alam setempat (geografis, geologis, dan iklim); sumber daya alam; sumber daya manusia; dan kebudayaan masyarakat setempat (Soetedjo, 1982: 97). 


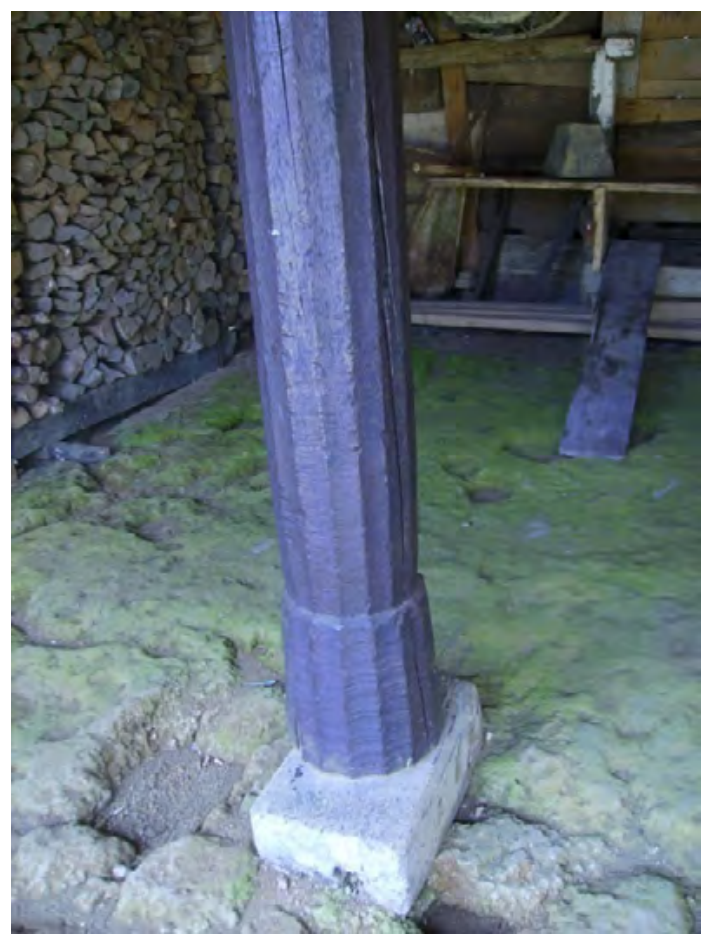

Gambar 6. Tiang rumah dan umpak. (Sumber: Dokumen Balai Arkeologi Palembang, 2007)

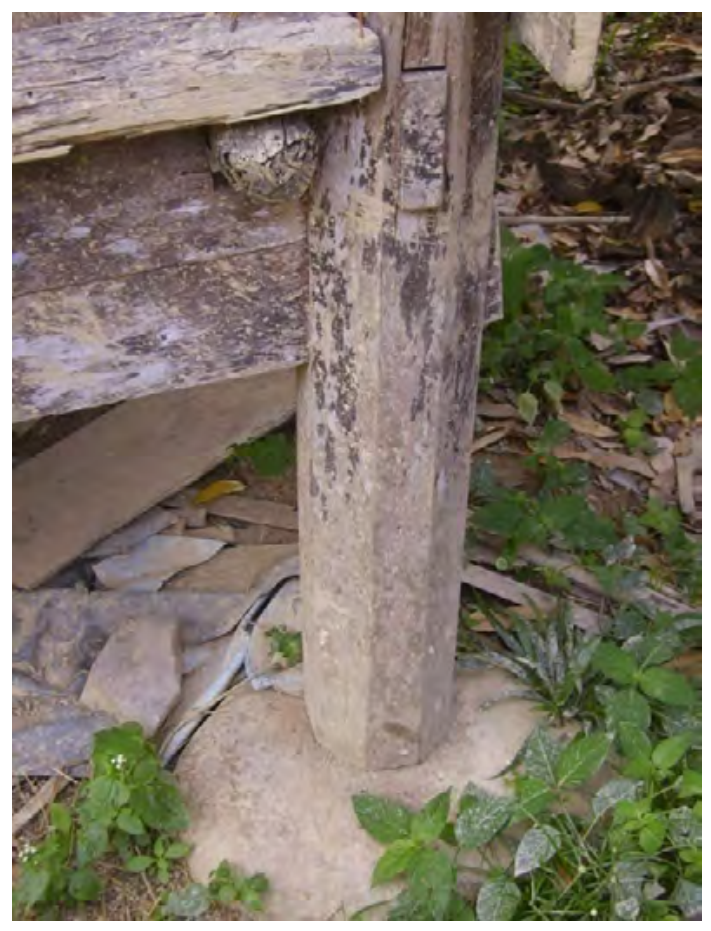

Gambar 7. Umpak tiang lumbung padi. (Sumber: Dokumen Balai Arkeologi Palembang, 2007)
Pertama, kondisi alam berpengaruh dalam hal konstruksi yang berdampak pada model rumahnya, contohnya model hunian pada daerah berrawa-rawa berbeda dengan di daerah kering. Kedua, sumber daya alam yang tersedia berpengaruh terhadap bahan baku, contohnya pada daerah tropis yang kaya akan kayu, model huniannya berbeda dengan daerah gurun pasir. Ketiga, sumber daya manusia tercermin pada pola pikir manusianya, semakin maju teknologi yang dikuasai manusianya maka bentuk huniannya semakin memenuhi unsur kekuatan dan keindahan. Keempat, kebudayaan masyarakat setempat berpengaruh terhadap model hunian, contohnya pada konsep pemikiran yang menempatkan alam jagat raya sebagai makrokosmos dan rumah sebagai cerminnya dalam bentuk mikrokosmos, menyatu dalam kesatuan kosmik totemik, memunculkan seni ragam hias pada sebuah bangunan yang menggambarkan alam lingkungan (Soetedjo, 1992: 97).

Faktor kondisi dan sumber daya alam kemungkinan menjadi pertimbangan utama dalam pembangunan rumah tradisional Suku Batin atau rumah kajang lako. Kondisi iklim tropis dan ketersediaan bahan baku (kayu) memungkinkan pemilihan bentuk rumah panggung dengan banyak tiang. Pemakaian tiang yang cukup banyak dan cukup tinggi dengan berbagai variasi bentuk dapat memberikan gambaran kondisi sosial dan ekonomi pemilik rumah. Kondisi sosial kebanyakan atau biasanya berbanding lurus dengan kondisi ekonomi. Dalam masyarakat, orang dengan status sosial yang lebih tinggi biasanya juga didukung perekonomian yang lebih mampu. Selain status sosial dan ekonomi, politik juga 
menjadi faktor yang memicu munculnya statifikasi sosial.

Tiang rumah Suku Batin berbentuk segi $6,8,12,16$, dan 18 . Bentuk tiang segienam tentunya berbeda dengan segidelapan, dua belas, dan seterusnya. Semakin banyak segi pada bentuk tiang semakin besar diameternya. Tentunya perbedaan bentuk tiang juga berpengaruh pada kekuatan tiang menyangga rumah. Semakin banyak segi pada tiang semakin besar diameter dan kekuatannya. Hal ini menunjukkan bahwa tiang rumah mempunyai arti atau fungsi praktis, sesuai dengan kaidah dalam teknik rancang bangun rumah. Rumah yang tidak terlalu besar, cukup didukung tiang yang kecil atau sedang, sesuai dengan beban yang didukungnya. Sedangkan rumah berukuran besar dengan beban yang juga besar, tentunya memerlukan tiang dengan diameter yang juga besar untuk memperkuat daya dukungnya. Kesesuaian pemakaian tiang selain mempertimbangkan alasan praktis, tentunya juga memperhatikan alasan estetis (keindahan). Rumah kecil tentunya tidak proporsional apabila didukung tiang besar sehingga akan kehilangan nilai estetisnya.

Selain menunjukkan besaran diameter dan kekuatannya, bentuk segi pada tiang ternyata juga menunjukkan status sosial pemilik rumah. Status sosial secara umum dapat diartikan sebagai sekumpulan hak dan kewajian yang dimiliki seseorang dalam masyarakatnya. Orang yang memiliki status sosial tinggi akan ditempatkan lebih tinggi dalam struktur masyarakat dibandingkan dengan orang yang status sosialnya rendah.

Ternyata, pemilik rumah Batin dengan bentuk tiang segi lebih banyak memiliki status yang lebih tinggi daripada bentuk tiang segi lebih sedikit. Pemilik rumah ini adalah orang yang sangat dihormati dalam masyarakat tersebut, seperti pemuka adat; alim ulama; ninik mamak; dan cerdik pandai. Hal ini mengindikasikan bahwa rumah dengan tiang berbentuk segi banyak hanya diperuntukkan bagi kalangan tertentu, tidak setiap orang bisa membuatnya. Fenomena keberadaan rumah tradisional Suku Batin dengan segala hal yang menyertainya ini sudah berlangsung sejak masa lalu sampai sekarang.

Selain bentuknya, tiang rumah dari kalangan status sosial tinggi juga dilengkapi dengan hiasan atau ornamen. Secara umum fungsi hiasan atau ornamen pada suatu benda atau barang yang dihias adalah untuk memperindah benda atau barang tersebut. Hiasan pada rumah tradisional suku Batin tersebut bisa berupa ukiran yang berada di dekat tiang atau benda tertentu yang diletakkan atau ditempelkan pada tiang tersebut. Benda yang ditempelkan pada tiang tersebut biasanya berupa binatang, yaitu bagian tanduk kerbau atau rusa.

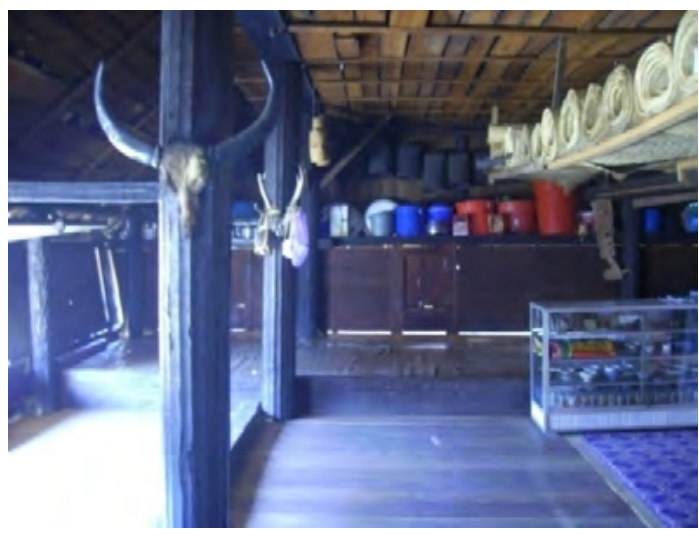

Gambar 8. Kepala dan tanduk rusa sebagai hiasan yang terdapat pada tiang. (Sumber: Dokumen Balai Arkeologi Palembang, 2007)

Bangsa Indonesia sejak zaman neolitik telah mengenal kerbau sebagai binatang 
ternak. Kerbau dapat digunakan untuk membantu mengolah tanah pertanian, juga dipuja sebagai binatang keramat. Penggambaran atau motif kerbau dalam ornamen Nusantara umumnya digunakan sebagai lambang kesuburan dan dipandang sebagai penolak bala. Sebagai lambang kesuburan, kerbau juga melambangkan dunia bawah. Bentuk tanduknya yang melengkung indah dihubungkan dengan bulan (Sunaryo, 2009: 122).

Adapun rusa termasuk binatang yang telahdiabadikan dalamornamen prasejarah, antara lain pada nekara perunggu. Hewan ini dianggap memiliki usia hidup yang panjang sehingga digunakan sebagai lambang kelestarian. Rusa adalah lambang kegesitan dan kebijaksanaan, terkait dengan kegesitan berpikir, mengambil tindakan, dan keputusan. Motif hias atau ornamen rusa dapat dijumpai pada rumah suci untuk dewa di Singaraja (Bali), relief candi Borobudur, pintu gerbang masjid Sendangduwur, batik pesisiran, dan kain tenun Sumba (Soetedjo, 1992: 139-144).

Pemilihan ornamen tanduk kerbau dan rusa pada tiang rumah tradisional suku Batin tentunya didasari alasan atau pertimbangan yang matang, bukan asal pasang. Pada suku Batin, penempatan ornamen tanduk kerbau dan rusa pada rumah tradisional melambangkan kelebihan/kekayaan/kekuasaan. Rumah tradisional Batin yang terdapat hiasan tanduk kedua binatang itu, umumnya milik kalangan atas. Sifat-sifat baik kedua binatang itu (penolak bala/pelindung, lestari, gesit, dan bijaksana) diharapkan dapat melekat pada (penghuni) rumah. Pemilik rumah yang mempunyai status sosial tinggi seharusnya memiliki sifatsifat baik tersebut sehingga menjadi panutan dalam masyarakatnya.
Kepemilikan benda tertentu sebagai penanda status tinggi juga dapat dilihat pada masyarakat di Toraja dan Nias Selatan. Masyarakat Toraja yang mempunyai status sosial tinggi dapat dilihat dari banyaknya tanduk kerbau (kabongo) yang ditempatkan pada tiang tongkonan (tulak somba). Pada Suku Naga di dataran tinggi Assam (antara Myanmar dan India) kepemilikan benda tertentu dapat menunjukkan tanda kebesaran, status sosial tinggi, prestise dan kekuasaan politik atau kelompoknya (Susilowati, 2007: 63).

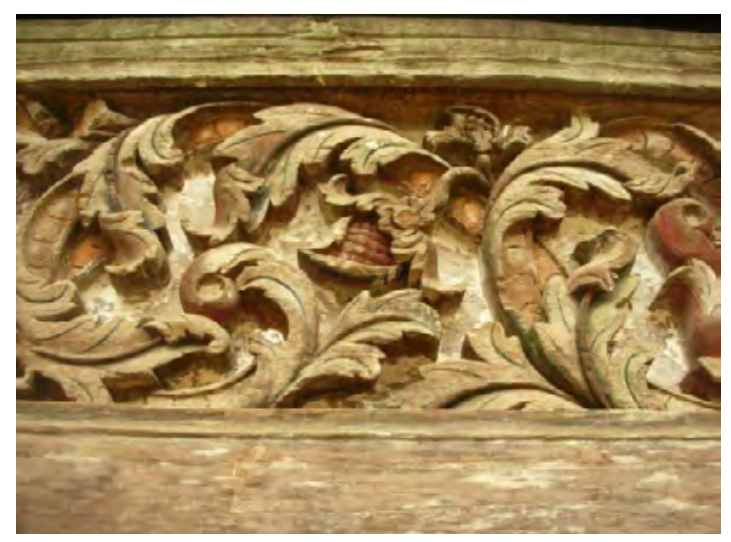

Gambar 9. Hiasan motif flora. (Sumber: Dokumen Balai Arkeologi Palembang, 2007)

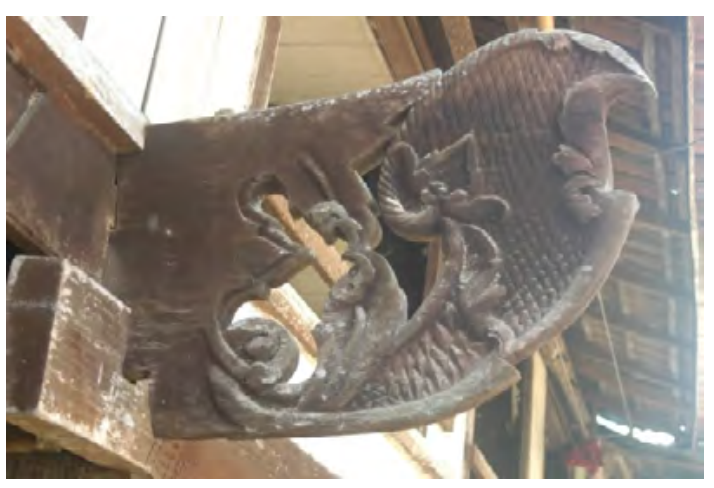

Gambar 10. Hiasan motif fauna (ikan). (Sumber: Dokumen Balai Arkeologi Palembang, 2007)

Rumah tradisional Suku Batin dari kalangan dengan status sosial tinggi biasanya dilengkapi dengan hiasan pada bagian tertentu, terutama pada bagian 
bendul. Ragam hias tersebut biasanya berupa motif flora/tumbuhan (bunga tanjung, tampuk manggis, bunga jeruk), dan motif fauna (ikan). Motif bunga tanjung ditempatkan di bagian depan masinding yang terbuat dari kayu tembesu. Motif tampuk manggis ditempatkan di bagian depan masinding dan di atas pintu. Motif bunga jeruk menghiasi bagian luar belandar dan di atas pintu.

Motif tumbuh-tumbuhan atau motif flora pada zaman prasejarah belum berkembang. Pada masa ini tidak terdapat ornamen tanaman, tetapi pada zaman pengaruh Hindu ornamen ini sangat umum dan sejak saat itu menjadi bagian utama dalam ornamentasi di Indonesia. Motif tumbuh-tumbuhan semakin subur dan mendapat tempat yang istimewa setelah datang pengaruh Islam sekitar abad ke-15. Sebaliknya, motif manusia dan binatang atau motif makhluk hidup yang beraneka di zaman Hindu semakin surut, bahkan di beberapa daerah ditinggalkan. Tidak selamanya motif flora mengandung makna simbolik, sebab seringkali variasi motif tumbuh-tumbuhan ornamen Nusantara lebih menekankan pada segi keindahan. Apalagi jenis tanaman yang digunakan sebagai motif hiasnya tidak teridentifikasi dengan jelas, artinya tidak menggambarkan jenis tanaman atau unsur tanaman tertentu (Susilowati, 2007: 153).

Motif fauna atau binatang yang dipahatkan pada rumah tradisional suku Batin adalah ikan. Hewan air ini digambarkan bersisik besar. Hasil ukirannya tidak berbentuk seperti ikan tetapi distilir ke dalam bentuk daundaunan yang dilengkapi dengan bentuk sisik ikan. Motif ikan ditempatkan di masing-masing ujung bendol gaho dan balik melintang. Motif ikan yang distilir tersebut kemungkinan menggambarkan ikan semah (Tor douronesis). Habitat ikan ini adalah daerah dataran tinggi (pegunungan) atau sungai beraliran deras. Ikan ini banyak hidup di daerah Kerinci dan Merangin.

Motif hias flora dan fauna yang terdapat di rumah tradisional Suku Batin tentunya diambil dari lingkungan sekitarnya. Dengan memperhatikan motif hias tersebut dapat menjadi kajian tersendiri tentang keberadaan tumbuhan dan binatang tersebut sekarang. Keberadaan ikan semah di Merangin sekarang mulai berkurang. Salah satu usaha untuk melestarikan ikan tersebut dilakukan dengan membentuk "lubuk larangan" pada beberapa desa.

\section{SIMPULAN}

Keberadaan rumah tradisional bukan hanya dilihat secara fisik sebagai sebuah bangunan semata, akan tetapi mengandung arti atau simbol tertentu. Arti atau simbol tersebut hanya dapat dipahami dengan memperhatikan hal-hal yang ada di balik keberadaan fisik bangunan tersebut. Hal tersebut secara langsung maupun tidak telah berlangsung lama dan menjadi kesepakatan tidak tertulis masyarakat setempat, bahkan masyarakat pada umumnya.

Kedudukan atau status seseorang dapat tercermin atau diperoleh dari kekayaan, ketinggian ilmu, dan kekuasaan yang dimilikinya. Seseorang yang mempunyai status sosial tinggi, salah satunya dapat dilihat dari rumah yang dimilikinya. Tiang rumah Batin berbentuk segi banyak hanya diperuntukkan bagi kalangan pemuka adat, alim ulama, ninik mamak, dan cerdik pandai. Rumah dengan tiang tersebut hanya diperuntukkan bagi orang 
atau tokoh yang mempunyai kedudukan terhormat.

Arsitektur vernakular Indonesia penuh dengan simbol-simbol. Banyak kesamaan simbol pada arsitektur vernakular Indonesia itu. Kesamaan simbol-simbol tersebut terjadi akibat adanya kesamaan pola pikir. Misalnya, komponen utama atau pendukung bangunan yang bagus dan raya diasumsikan atau dikaitkan dengan pemilik dari kalangan atau strata tertentu (tinggi).

\section{DAFTAR PUSTAKA}

Balai Arkeologi Palembang. 2007. Penelitian Arkeologi di Provinsi Jambi. Palembang: Balai Arkeologi Palembang.

Darmansyah. 2002. Arsitektur Rumah Tradisional Suku Batin: Arti dan Fungsinya. Jurnal Arkeologi Sidhayatra VII (2)/2002: 12-24.

Herusatoto, Budiono. 2008. Simbolisme Jawa. Yogyakarta: Ombak.

Madjid, Anas., dkk. 1986. Arsitektur Tradisional Daerah Jambi. Jakarta: Proyek Inventarisasi dan Dokumentasi Kebudayaan Daerah, Departemen Pendidikan dan Kebudayaan.

Nas, Peter J.M. 1998. The House in Indonesia Between Globalization and Localization. Bijdragen Tot de Taal-, Land- en Volkenkunde, 154ii: 335-360.

Riany, Meta., dkk. 2014. Kajian Aspek Kosmologi-Simbolisme pada Arsitektur Rumah Tinggal Vernakular di Kampung Naga. Jurnal Online Reka Karsa 2(4): 1-12.

Siregar, Sondang M. 2008. Kampung Lama di Situs Baruh, Kabupaten Merangin (Aset Budaya yang Perlu Dilestarikan). Proseding Pertemuan Ilmiah Arkeologi XI: 535-542. Solo, 13 - 15 Juni 2008: Ikatan Ahli Arkeologi Indonesia.

Soekanto, Soerjono. 2012. Sosiologi Suatu Pengantar. Jakarta: Rajawali Pers.

Soetedjo, Suwondo. 1982. Pencerminan Nilai Budaya dalam Arsitektur Indonesia. Jakarta: Penerbit Djambatan.

Sumintardja, Djauhari. 1981. Kompendium Sejarah Arsitektur Jilid I. Bandung: Yayasan Lembaga Pendidikan dan Masalah Bangunan.

Sunaryo, Aryo. 2009. Ornamen Nusantara. Semarang: Effhar Offset.

Susilowati, Nenggih. 2007. Kerbau dalam Tradisi Megalitik Etnis Batak di Sumatera Utara. Sangkhakala Berkala Arkeologi, X (19): 63-71.

Syarbaini, Syahrial, Rusdiyanta, dan Fatkhuni. 2012. Konsep Dasar Sosiologi \& Antropologi. Teori dan Aplikasi. Jakarta: Hartomo Media Pustaka.

Waterson, Roxana. 1997. The Living House. An Anthropology of Architecture in South-East Asia. London: Thames and Hudson.

Wiyana, Budi., dkk., 2000. Penelitian Penjajakan Arkeologi Islam di Kabupaten Merangin, Provinsi Jambi. Laporan Penelitian. Palembang: Balai Arkeologi Palembang.

Wiyana, Budi. 2007. Pola Permukiman Islam Kuna di Kabupaten Merangin Provinsi Jambi. Laporan Penelitian. Palembang: Balai Arkeologi Palembang. 
PURBAWIDYA ם Vol. 5, No. 1, Juni 2016 